\title{
Detection of invA gene of Salmonella from milkfish (Chanos chanos) at Sidoarjo wet fish market, Indonesia, using polymerase chain reaction technique
}

\author{
Sheila Marty Yanestria ${ }^{1}$, Reina Puspita Rahmaniar ${ }^{2}$, Freshinta Jellia Wibisono ${ }^{1}$ and Mustofa Helmi Effendi ${ }^{3}$
}

\author{
1. Department of Veterinary Public Health, Faculty of Veterinary Medicine, Wijaya Kusuma University, Surabaya, \\ Indonesia; 2. Department of Microbiology, Faculty of Veterinary Medicine, Wijaya Kusuma University, Surabaya, \\ Indonesia; 3. Department of Veterinary Public Health, Faculty of Veterinary Medicine, Airlangga University, Surabaya, \\ Indonesia. \\ Corresponding author: Mustofa Helmi Effendi, e-mail: mheffendi@yahoo.com \\ Co-authors: SMY: sheila.marty11.sm@gmail.com, RPR: puspita.reina@gmail.com, FJW: freshinta.uwks@gmail.com \\ Received: 03-09-2018, Accepted: 07-12-2018, Published online: 29-01-2019
}

doi: 10.14202/vetworld.2019.170-175 How to cite this article: Yanestria SM, Rahmaniar RP, Wibisono FJ, Effendi MH (2019) Detection of invA gene of Salmonella from milkfish (Chanos chanos) at Sidoarjo wet fish market, Indonesia, using polymerase chain reaction technique, Veterinary World, 12(1): 170-175.

\begin{abstract}
Aim: The study aimed to detect the invA gene in Salmonella isolated from milkfish in the Sidoarjo wet fish market.

Materials and Methods: A total of 84 samples were prepared in enrichment media and isolated on the surface of Salmonella Shigella Agar. Salmonella growth produces transparent colonies with blackish color in the middle due to $\mathrm{H}_{2} \mathrm{~S}_{\text {gas }}$ formation. Samples were identified as Salmonella based on macroscopic colony morphology. Presumptive Salmonella sp. was put on Bismuth Sulfite Agar media. Salmonella was determined based on the results of the biochemical test that has been carried out using Microbact identification kits from negative gram staining.
\end{abstract}

Results: The results of this study indicate that 32 of 84 samples (38.09\%) were Salmonella bacteria. Furthermore, the invA gene detection was carried out using the polymerase chain reaction technique. Electrophoresis results showed four positive samples contained invA gene with a length of $284 \mathrm{bp}$.

Conclusion: Results in this study indicate that contamination of milkfish with Salmonella needs strict hygienic measures to prevent their transmission to human.

Keywords: human health, invA gene, milkfish, polymerase chain reaction, Salmonella.

\section{Introduction}

Indonesia is an agricultural country that has a large enough fishery potential. The amount of capture fisheries production in 2014 was 6.20 tons, an increase of 0.34 million tons from 2013 which was only 5.86 million tons. The amount of fish production from the aquaculture sector has also increased from year to year [1]. Some fish products contaminated with bacteria can cause a disease called foodborne disease. Foodborne disease or also called foodborne diarrheal disease is a zoonotic disease and is found throughout the world. Foodborne diarrheal disease is a disease transmitted by animal's carriers that are healthy to humans through food contamination [2].

One of the bacteria that cause foodborne disease is Salmonella and is called salmonellosis. This disease is endemic in almost all major cities in Indonesia, and the incidence of typhoid fever caused by Salmonella typhi continues to increase with the incidence of 350-810 cases per 100,000 population

Copyright: Yanestria, et al. Open Access. This article is distributed under the terms of the Creative Commons Attribution 4.0 International License (http://creativecommons.org/licenses/ by/4.0/), which permits unrestricted use, distribution, and reproduction in any medium, provided you give appropriate credit to the original author(s) and the source, provide a link to the Creative Commons license, and indicate if changes were made. The Creative Commons Public Domain Dedication waiver (http:// creativecommons.org/publicdomain/zero/1.0/) applies to the data made available in this article, unless otherwise stated. with a mortality rate of $2 \%$. Typhoid fever is found throughout the year [3]. There are several transmission routes for salmonellosis, but the majority of human infections are derived from the consumption of contaminated foods, especially those of animal origin. Most cases of salmonellosis in fish start from consuming raw fish meat without first processing and cross-contamination [4]. The US Food Drug Administration reports data that Salmonella is the most common contaminant bacteria found in fish and fish products [5]. Established conventional methods to detect and identify Salmonella are time-consuming and include selective enrichment and plating followed by biochemical tests [6].

Salmonella detection can be done in various ways, one of which is using the polymerase chain reaction (PCR) technique. This technique can be used on very complex sample substances such as food and is able to work quickly and specifically. Due to the advantages, PCR is suitable to detect the presence of Salmonella. Detection of Salmonella using PCR can be done in a short time with high accuracy so that appropriate handling can be done on food [7]. The invA gene from Salmonella contains unique DNA sequences and is proven to be a PCR target gene suitable for Salmonella detection [8].

In this research, samples from milkfish were tested for isolation of Salmonella, by culturing and 
biochemical method, and then, they were confirmed by invA gene-specific PCR methods.

\section{Materials and Methods \\ Ethical approval}

Fresh milkfish were used in this study; hence, ethical approval was not necessary. Milkfish samples were collected from Sidoarjo wet fish market.

\section{Salmonella culture method}

Milkfish samples are cut with a sterilized knife. Grind the meat and digestive tract of the fish in a mortar with a stemper, then take $1 \mathrm{~g}$ and put it in $5 \mathrm{ml}$ of selenite broth, and incubate it for $24 \mathrm{~h}$ at $37^{\circ} \mathrm{C}$.

Bacterial isolation is carried out by taking bacterial suspensions with inoculating loop which is first sterilized using Bunsen fire. The suspension is then implanted in Salmonella Shigella Agar (SSA) which has been labeled according to the sample using the streak method to obtain a separate colony which is then incubated for $24 \mathrm{~h}$ in a temperature of $35-37^{\circ} \mathrm{C}$. The growth of Salmonella produces transparent or colorless colonies with blackish color in the middle due to $\mathrm{H}_{2} \mathrm{~S}$ gas formation [9]. Presumptive Salmonella is put on Bismuth Sulfite Agar (BSA) media. Bismuth sulfite is a selective medium for Salmonella isolation in the laboratory. BSA is a modification of Wilson and Blair Formula. Typhoid-causing organisms grow well in this medium, with the characteristics of black colonies. Gram-positive and other coliform bacteria are inhibited. These media are generally used for the detection of Salmonella species.

\section{Microscopic examination and biochemical test}

Positive samples on BSA media were then given Gram staining to determine the type of Gram bacteria that grew. Positive results on Gram examination show that bacteria in the form of long and medium rods, red, Gram-negative bacteria spread perfectly without forming long chains or groups [10]. After Gram staining, the bacteria were tested with biochemical tests [11]. The Salmonella was determined based on the results of the biochemical test that has been carried out using Microbact identification kits from OXOID.

\section{DNA extraction}

The initial step of PCR is DNA extraction of bacterial culture in Salmonella Shigella media to be extracted by boiling method. The boiling method was carried out for $10 \mathrm{~min}$ and centrifuged for $5 \mathrm{~min}$ at a speed of $6000 \mathrm{rpm}$. The supernatant is used for PCR amplification.

\section{PCR amplification}

Detection of Salmonella invasive encoding gene was carried out using the PCR test. The reagents for PCR amplification consisted of $2.5 \mu 1$ DNA template, 5 units of GoTaq DNA polymerase, $1 \times$ GoTaq PCR reaction buffer (containing $1.5 \mathrm{mM}$ $\mathrm{MgCl}$ ), $0.2 \mathrm{mM}$ PCR nucleotide mix, and $0.6 \mu \mathrm{M}$ DNA primers with a final volume of $50 \mu$ l. Specific primers used to detect Salmonella are primary forward (invA) GTG AAA TTA TCG CCA CGT TCG
GGC AA and primer reverse TCA TCG CAC CGT CAA AGG AAC C [12].

The PCR reagent mixture was then put in a thermocycler with an initial incubation of $94^{\circ} \mathrm{C}$ for $1 \mathrm{~min}$, followed by 35 cycles consisting of $94^{\circ} \mathrm{C}$ for denaturation for $1 \mathrm{~min}$, annealing at $58.3^{\circ} \mathrm{C}$ for $30 \mathrm{~s}$, and $72^{\circ} \mathrm{C}$ elongation for $30 \mathrm{~s}$ followed by the final extension at $72^{\circ} \mathrm{C}$ for $7 \mathrm{~min}$. Each of the $3 \mu \mathrm{l}$ of amplification products was mixed with $3 \mu 1$ of loading solution until well mixed.

\section{Electrophoresis of PCR products}

The results of PCR product amplification were electrophoresis in $1.5 \%$ agarose gel and stained with ethidium bromide. Markers are also inserted into the agarose gel well to determine the DNA size of the PCR product; then, electrophoresis is run for $40 \mathrm{~min}$ with a constant voltage of $100 \mathrm{v}$. Electrophoresis results were observed under ultraviolet light. The results obtained are DNA band patterns (DNA bands) which show different numbers and patterns. $100 \mathrm{bp}$ DNA ladder was used as a marker.

\section{Sensitivity and specificity of PCR [13]}

PCR assay was evaluated in various concentration of DNA and various concentration of viable Salmonella Typhimurium for analyzing sensitivity of PCR. For sensitivity test based on DNA concentration, DNA extract was sequentially diluted ten-folds and based on the viable bacterial count, $S$. Typhimurium was sequentially diluted from $10^{9}$ to 1 colony-forming unit $/ \mathrm{mL}$, and DNA was extracted from each dilution. DNA extracted from Staphylococcus aureus was used as negative control, in each PCR run. The PCR products were visualized by electrophoresis and observed as described above. The minimum concentration of DNA giving a positive signal was recorded. The specificity of PCR was evaluated by comparing with six different Salmonella serovars and cross-tested with 5 non-Salmonella isolates, i.e., Escherichia coli, Listeria monocytogenes, Proteus mirabilis, S. aureus, and Vibrio parahaemolyticus [13].

\section{Results and Discussion}

\section{Results of Salmonella culture and identification}

Testing on SSA media is done by macroscopic observation. On macroscopic examination, Salmonella growth produces transparent or colorless colonies with blackish color in the middle due to $\mathrm{H}_{2} \mathrm{~S}$ gas formation (Figure-1). Macroscopic colony examination results on SSA media same on BSA media that showed 32 positive samples from 84 samples (38.09\%) (Figure-2) and is shown in Table-1. These results were determined as Salmonella on Gram staining (Figure-3) and biochemical test (Figure-4).

\section{Detection of encoding gene Salmonella}

The results of detection of Salmonella invasive encoding genes performed using PCR tests shown in Figure-5, which shows positive Salmonella invA genes at $284 \mathrm{bp}$, and Salmonella which did not have invA genes (Figure-6). 


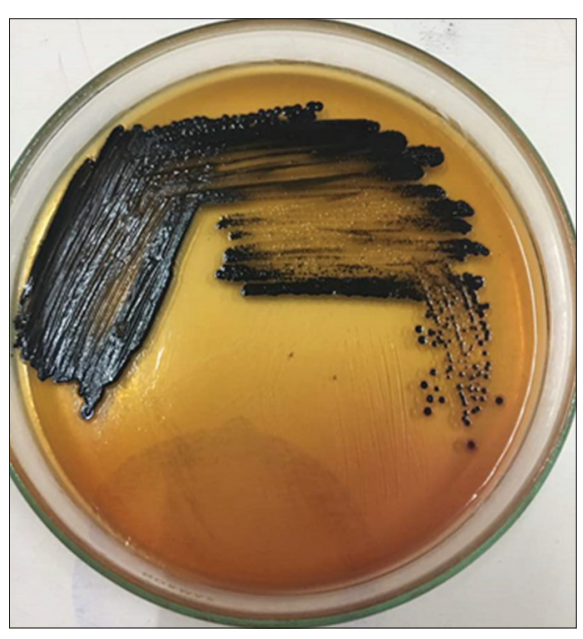

Figure-1: Result of Salmonella bacterial culture on Salmonella Shigella Agar media.

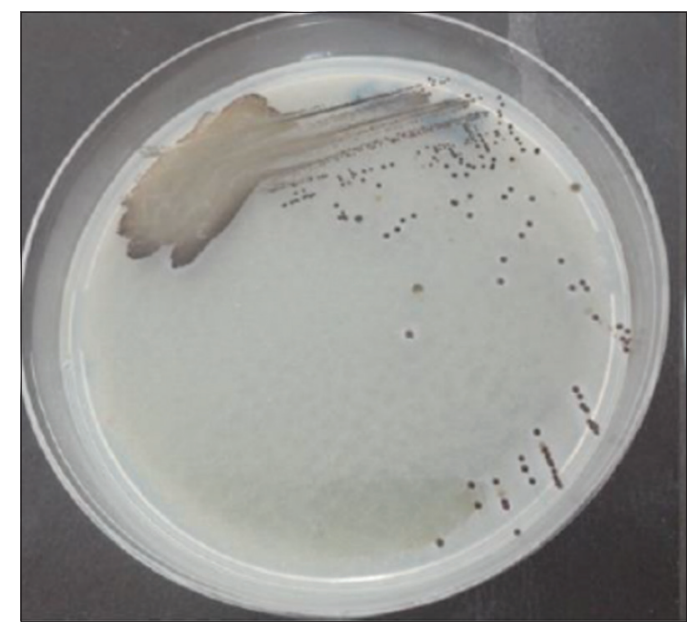

Figure-2: Result of Salmonella on Bismuth Sulfite Agar media.

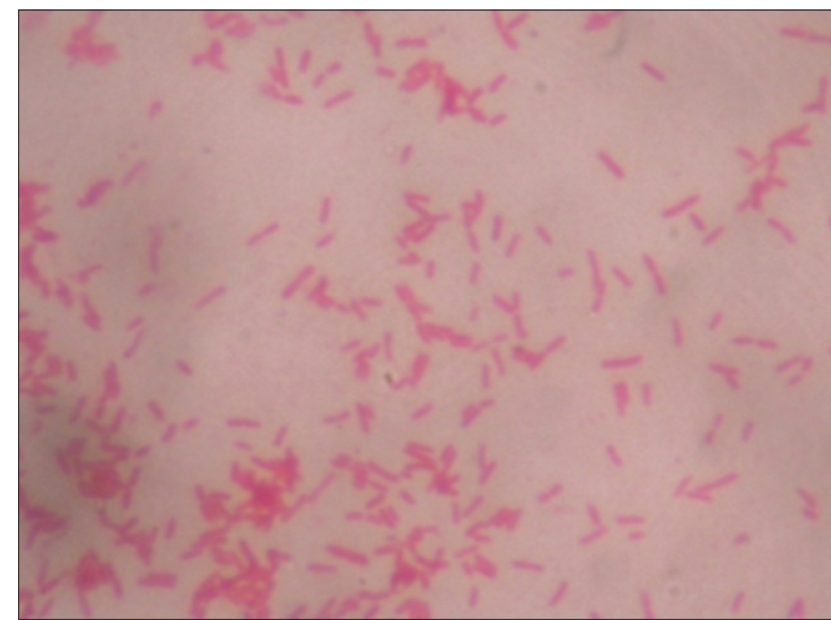

Figure-3: Microscopic examination result of Salmonella with negative Gram staining.

Salmonella infection is a major bacterial disease in fishes, poultry, and humans, causing significant economic loss and illnesses $[10,14,15]$. Out of 84 samples, we isolated 32/84 (38.09\%) of Salmonella by conventional culture method, and out of 32 positive Salmonella, we confirmed by PCR 4/32 (12.5\%).

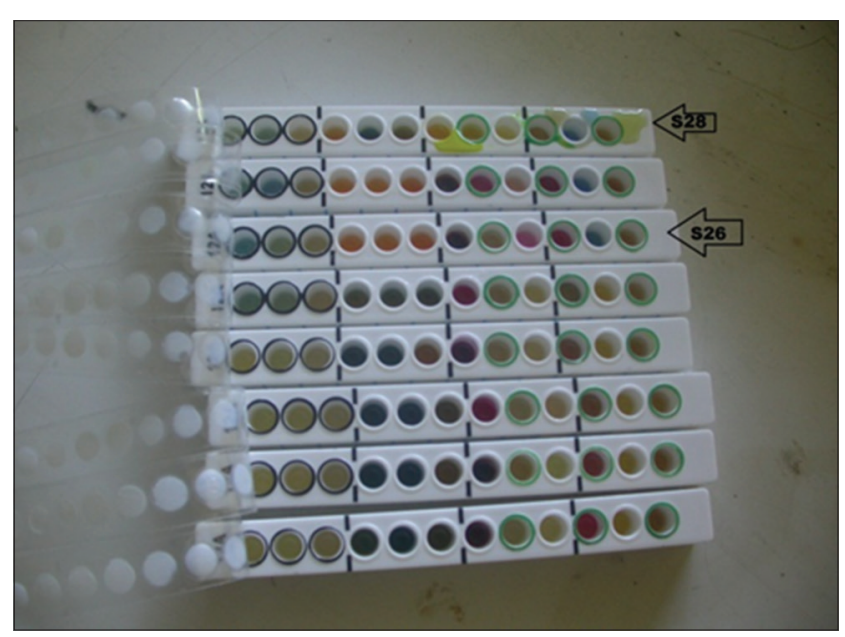

Figure-4: Positive Salmonella on biochemical test results using Microbact identification kits (arrows indicate positive Salmonella).

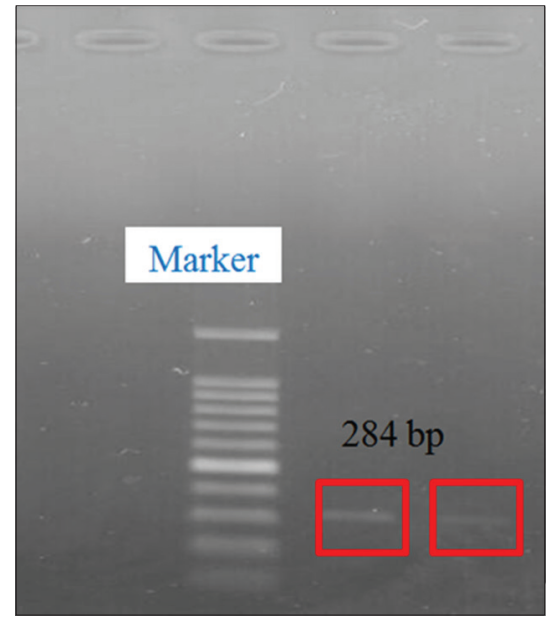

Figure-5: Results of detection of invA gene encoding Salmonella on milkfish.

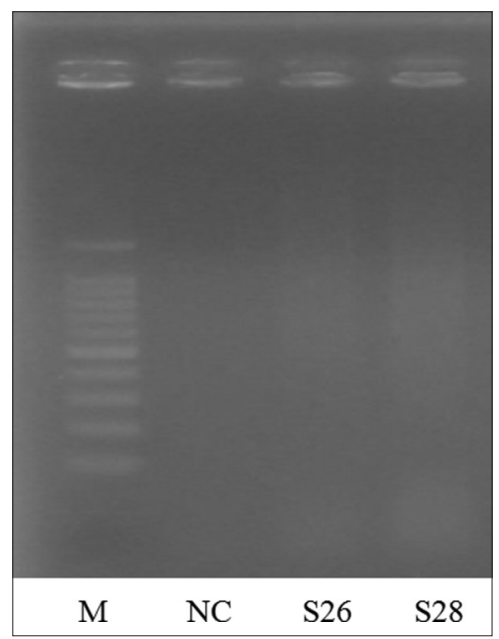

Figure-6: DNA visualization of invA gene Salmonella amplification products on a $1.5 \%$ agarose gel (tris-borateethylenediaminetetraacetic acid). Lane M=DNA marker 100 bp ladder, lane $\mathrm{NC}=S$. aureus DNA as a negative control, lane S26; S28 positive Salmonella without positive result of invA gene Salmonella.

Based on the results of PCR, there were 4 samples from 32 samples of Salmonella isolates which 
detected an invA gene with a length of $284 \mathrm{bp}$, while 28 samples did not show the target band. The absence of target bands in 28 samples showed that the strains of Salmonella bacteria obtained were not invasive or might also use other invasive mechanisms [16]. The use of certain PCR methods from InvA gene in most diagnostic and research laboratories is possible, and through molecular identification techniques of Salmonella, this method is the simplest and cheaper method [6].

At present, Salmonella is detected by standards bacteriological, biochemical, and serological techniques. These techniques are generally time-consuming, tedious, and expensive [17]. This research also corroborates some of the previous work carried out using the PCR method, in which non-typhoidal Salmonella was isolated from animals, food, and samples of human excrement in developing countries [18]. The observed prevalence of invasive Salmonella genes from poultry and poultry products is different from some other studies, which report a higher prevalence [6]. This variation may be due to differences in research methodology; gene-specific involvement, sample type, sample size and hygiene practices on the farm, and geographical location. Salmonella is known to infect animal products by various species; however, one serovar may be dominant in location for many years before being replaced by another. The most common and clinically significant serovar containing the $\operatorname{inv} A$ virulence gene that causes salmonellosis globally is $S$. Typhimurium and Salmonella enteritidis [19].

Molecular methods are increasingly important in detecting and typing Salmonella. Tests are published with the aim of replacing traditional serotyping with direct detection of various genes [20]. PCR examination technique with the invA gene is very sensitive and specific in detecting Salmonella. Detection of Salmonella-specific by PCR with primers for invA gene is fast, sensitive, and specific to detect Salmonella in many clinical samples [21]. This research supports the ability of this specific primer set to confirm isolates as Salmonella. The invA gene contains sequences specific to the genus Salmonella and is considered the international standard for its characterization [16].

The invA gene is indeed targeted for the diagnosis of Salmonella organisms at the genus level [22]. Salmonella-specific primers' ability to detect Salmonella species quickly and accurately in this study is mainly due to the primers sequence selected from the invasion of the $S$. Typhimurium gene as previously reported by Darwin and Miller [23]. This is also consistent with research conducted by Pererat and Murray [24] that the results of PCR on various serotypes of Salmonella showed positive results, while PCR results on non-Salmonella strains such as E. coli, Klebsiella, Proteus, and Shigella were negative for the inv $A$ gene.
Table-1: Results of Salmonella isolation and invA gene detection.

\begin{tabular}{lccc}
\hline & Milkfish samples & Salmonella & invA gene \\
\hline $\begin{array}{l}\text { Total } \\
\text { number }\end{array}$ & 84 & 32 & 4 \\
\hline
\end{tabular}

First step in the intracellular pathogenicity cycle of Salmonella is the invasion of intestinal epithelial cells, and this step is controlled by the inv $A$ gene. The invA gene encodes proteins in bacterial cell membranes that are needed for invasion into host epithelial cells $[23,25]$. This gene is located in pathogenicity island I or referred to as Salmonella Pathogenicity Island (SPI); the DNA region is related to the pathogenicity of Salmonella enterica and is owned by all serotypes [26]. SPI serves to add complex virulence by bacteria to the infected host [24].

Many invasion genes encoded in SPI I and their expression are activated by the HilA gene; transcription factors are also encoded in SPI I. In a study conducted by Murray and Lee [26] regarding the role of Salmonella invasion genes during infection in mice after intragastric inoculation, it was found that strains containing invasion genes that had mutations were found from intestinal tissue cells, and systemic tissue compared to strains that had not undergone previous mutation.

Galan et al. [27] also identified the invA gene as the first gene consisting of at least two additional invasion genes that are Salmonella to enter culture epithelial cells, but now there is an invA gene that has mutations. S. Typhimurium invA mutants are less capable of invading culture epithelial cells. InvA mutants do not alter the normal structure of the microvilli of epithelial cells and also do not cause changes in the distribution of actin microfilaments from cells. InvA mutants are significantly inhibited in their ability to enter cells, no emergence of invasive gene bands can also be caused by mutant genes that are unable to replicate on the intestinal mucosal surface, it can also be caused due to susceptibility to bactericidal host factors such as phagocytes. The invasion gene has been found in Salmonella with its ability to kill phagocytes in vitro.

With PCR, a single gene product can be strengthened in a single PCR reaction and in this study is shown as a rapid method for identifying one gene related to invasion virulence. Such early detection can have major benefits in public health, especially for rapid diagnosis and finding the ideal vaccine, epidemiological investigations, and prophylactic strategies for Salmonellosis in Sidoarjo, Indonesia. In summary, the findings from this study showed the distribution of invA gene (12.5\%) in milkfish sources (Table-1). This requires planning and implementing control programs to prevent and control infections for spreading to public health. 


\section{Conclusion}

This study describes the prevalence of Salmonella contamination in the milkfish samples obtained from Sidoarjo wet fish market, Indonesia. The study found contamination of Salmonella in milkfish, indicating potential sources and routes of the Salmonella transmission in the fishery. Isolation of Salmonella carrying invasion gene (InvA gene) in this study could show poor sanitation of the environment in which milkfish are sold at wet fish market Sidoarjo, East Java Province, Indonesia.

\section{Authors' Contributions}

MHE supervised the project. SMY was a project leader and RPR carried out bacterial isolation and molecular work. FJW collected the samples. All authors contributed in the drafting and revision of the manuscript. All authors read and approved the final manuscript.

\section{Acknowledgments}

The authors would like to thank the Ministry of Research, Technology and Higher Education of Indonesia for providing research funds with grant number; 16/LPPM/UWKS/III/2018 for the research title: DETEKSI DAN KARAKTERISASI Salmonella spp. PADA IKAN BANDENG (Chanos chanos) DI TEMPAT PELELANGAN IKAN KABUPATEN SIDOARJO.

\section{Competing Interests} interests.

The authors declare that they have no competing

\section{Publisher's Note}

Veterinary World remains neutral with regard to jurisdictional claims in published institutional affiliation.

\section{References}

1. Ministry of Maritime Affairs and Fisheries. (2015) A Report on Trends In Coastal Marine Resources And Fisheries Management in Indonesia.

2. Kakatkar, A., Gautam, S., Nagar, R.K., Karani, V. and Bandekar, J.R. (2010) Incidence of food-borne pathogens in freshwater fish from domestic markets of Mumbai. Fish. Technol., 47(2): 195-200.

3. Poeloengan, M., Komala, I. and Noor, S.M. (2014) Bahaya Salmonella Terhadap Kesehatan. Prosiding Lokakarya Nasional Penyakit Zoonosis, p216-224.

4. Hassan, R., Tecle, S., Adcock, B., Kellis, M., Weiss, J., Saupe, A., Sorenson, A., Klos, R., Blankenship, J., Blessington, T., Whitlock, L., Carleton, H.A., Concepción Acevedo, J., Tolar, B., Wise, M. and Neil, K.P. (2018) Multistate outbreak of Salmonella Paratyphi B variant L(+) tartrate $(+)$ and Salmonella Weltevreden infections linked to imported frozen raw Tuna - United States, 2015. Epidemiol. Infect., 146(11): 1461-1467.

5. Olgunoğlu, I. A. (2012) In: Mahmoud, B.S. M., editor Salmonella - A Dangerous Foodborne Pathogen. Published by InTech, Janeza Trdine 9, 51000 Rijeka, Croatia. p 91-108.

6. Shanmugasamy, M., Velayutham, T. and Rajeswar, J. (2011)
InvA gene-specific PCR for detection of Salmonella from broilers. Vet. World, 4(12): 562-564.

7. Prayoga, W., dan Wardani, A.K. (2015), Polymerase chain reaction for detection of Salmonella spp.: Literature review. J. Pangan Agroindu., 3(2): 483-488.

8. Abdel-Aziz, N.M. (2016) Detection of Salmonella species in chicken carcasses using genus-specific primer belong to invA gene in Sohag city, Egypt. Vet. World, 9(10): $1125-1128$.

9. Ibrahim, B. and Sheshi, M. (2014) Isolation and identification of bacteria associated with fresh and smoked fish (Clarias gariepinus) in Minna metropolis, Niger state. Nigeria. J. Appl. Environ. Micro., 2(3): 81-85.

10. Nidaullah, H., Abirami, N, Shamila-Syuhada, A.K., Chuah, L.O., Nurul, H., Tan, T.P., Zainal, A.F.W. and Rusul, G. (2017) Prevalence of Salmonella in poultry processing environments in wet markets in Penang and Perlis, Malaysia. Vet. World, 10(3): 286-292.

11. Todar, K. (2005) Salmonella and Salmonellosis. Todar's Online Textbook of Bacteriology. (c) 2005 Kenneth Todar University of Wisconsin-Madison Department of Bacteriology, USA.

12. Upadhyay, B.P., Utrarachkij, F., Thongshoob, J., Mahakunkijcharoen, Y., Wongchinda, N., Suthienkul, O. and Khusmith, S. (2010) Detection of Salmonella invA gene in shrimp enrichment culture by polymerase chain reaction. Southeast Asian J. Trop. Med. Public Health, 41(2): 426-435.

13. Amalia, U., Dewanti-Hariyadi, R. and Poernomo, A. (2014) Rapid detection of Salmonella in shrimp by polymerase chain reaction. J. Teknol. Ind. Pangan, 25(1): 78-82.

14. Bibi, F., Qaisrani, S.N., Ahmad, A.N., Akhtar, M., Khan, B.N. and Ali, Z. (2015), Occurrence of Salmonella in freshwater fishes: A review. J. Anim. Plant Sci., 25(2): 303-310.

15. Whiley, H. and Ross, K. (2015) Salmonella and eggs: From production to plate. Int. J. Environ. Res. Public Health, 12(3): 2543-2556.

16. Malorny, B., Hoorfar, J., Bunge, C. and Helmuth, R. (2003) Multicenter validation of the analytical accuracy of Salmonella PCR: Towards an international standard. Appl. Environ. Microbiol., 69(1): 290-296.

17. Hernandez, T., Sierra, A., Rodriguez-Alvarez, C., Torres, A., Arevalo, M.P., Calvo, M. and Arias, A. (2005) Salmonella Enterica serotypes isolated from imported frozen chicken meat in Canary Islands. J. Food Prot., 68(12): 2702-2706.

18. Suwit, C., Suvichai, R., Fred, U., Pakpoom, T. and Prapas, P. (2014) Prevalence and antimicrobial resistance of Salmonella isolated from carcasses, processing facilities and the environment surrounding small scale poultry slaughterhouses in Thailand. Southeast Asian J. Trop. Med. Public Health, 45(6): 1392-1400.

19. Rodriguez, J., Rondón, I. and Verjan, N. (2014) Serotypes of Salmonella in broiler carcasses marketed at Ibague, Colombia. Braz. J. Poult. Sci., 17(4): 545-552.

20. Kardos, G., Farkas, T., Antal, M., Nógrády, N. and Kiss, I. (2007) Novel PCR assay for identification of Salmonella Enterica serovar infantis. Lett. Appl. Microbiol., 45(4): 421-425.

21. Lampel, K.A., Orlandi, P.A. and Kornegay, L. (2000) Improved template preparation for PCR-based assay for detection of food-borne bacterial pathogens. Appl. Environ. Microbiol., 66(10): 4539-4542.

22. Abdeltawab, A.A.E., Ahmed, A.M., Aisha, A.R., Fatma, H.I.E. and Mohammed, E.E.S.A. (2013) Detection of common $(\operatorname{inv} A)$ gene in salmonellae isolated from poultry using polymerase chain reaction technique. Benha Vet. Med. J., 25(2): 70-77.

23. Darwin, K.H. and Miller, V.L. (1999) Molecular basis of the interaction of Salmonella with the intestinal mucosa. Clin. Microbiol. Rev., 12(3): 405-428.

24. Pererat, K. and Murray, A. (2008) Development of a PCR 
assay for the identification of Salmonella Enterica serovar Brandenburg. J. Med. Microbiol., 57(3): 1223-1227.

25. Sharma, I. and Das, K. (2016) Detection of invA gene in isolated Salmonella from marketed Poultry. J. Food Process Technol., 7(1): 3.

26. Murray, R.A. and Lee, C.A. (2000) Invasion genes are not required for Salmonella enterica serovar Typhimurium to breach the intestinal epithelium: Evidence that Salmonella pathogenicity island 1 has alternative functions during infections. J. Infect. Immun., 68(9): 5050-5055.

27. Galan, J.E., Ginocchio, C. and Costeas, P. (1992) Molecular and functional characterization of the Salmonella invasion gene invA: Homology of invA to members of a new protein Family. J. Bacteriol., 174(13): 4338-4349.

$* * * * * * * *$ 